Working Paper 11-29

Economic Series

August, 2011
Departamento de Economía Universidad Carlos III de Madrid

Calle Madrid, 126

28903 Getafe (Spain)

Fax (34) 916249875

\title{
The Rise and Fall of Centralized Wage Bargaining
}

\author{
Salvador Ortigueira* \\ Universidad Carlos III de Madrid ${ }^{\dagger}$
}

August 29, 2011

\begin{abstract}
During the three decades spanning the early 50's to the early 80 's, the wagesetting process in most Northern European countries was dominated by centralized bargaining, where peak level labor and employer associations set wages nationwide. In the early 80's centralized wage bargaining began to collapse. In this paper we assess a novel explanation both for the initial establishment of a centralized wagesetting process, and for its subsequent collapse. According to our theory, centralized wage bargaining was set up as a response to the spillovers created by the unemployment benefit program. Its collapse was the result of the increase in the productivity gap across workers, brought about by equipment-specific technological progress and equipment-skill complementarity.
\end{abstract}

Keywords: Wage-Bargaining Arrangements; Unemployment Benefits; Equipment-Specific Technological Progress; Equipment-Skill Complementarity.

JEL Classification Numbers: J31; J41; J51.

\footnotetext{
${ }^{*}$ I thank the comments of two referees and the Editor. I am also grateful to seminar participants at the University of Pennsylvania, Cornell, Penn State, Arizona State, Southampton, The European University Institute, St. Andrews, Humboldt-Berlin, Bilbao, the EU Institute in Tokyo and at Osaka University. Financial support from the Spanish Ministerio de Ciencia e Innovación under grant 2011/00049/001 is gratefully acknowledged.

${ }^{\dagger}$ Department of Economics, Universidad Carlos III de Madrid. Calle Madrid 126, 28903 Getafe (Spain). E-mail: Salvador.Ortigueira@uc3m.es.
} 


\section{Introduction}

From the end of the Second World War until the early 80's, labor unions in Northern European countries combined into a unions' federation which was mandated to meet with the employers' association and negotiate wages nationwide. This wage-setting arrangement reached its maximum strength in the heavily unionized Scandinavian economies - Denmark, Finland and Sweden - and has been referred to as the Scandinavian model or the centralized wage-bargaining model. Existing quantitative measures of centralization in wage-bargaining show that this arrangement began to collapse in the early 80's, and that it went on declining at least until the mid 90's. Furthermore, the chronology of events in Sweden supports the hypothesis that the collapse of centralized bargaining was the result of a breakdown in the unions' alliance [see e.g. Freeman and Gibbons (1995)].

In view of these facts we construct a macroeconomic model intended to provide answers to the following questions: Why did labor unions choose to form a federation and engage in centralized wage negotiations in the first place? What made labor unions change their strategies and undertake their own wage negotiations, abandoning an arrangement that had proved useful for 30 years?

Previous literature (we review key contributions in the next section) has made clear that centralization was brought about by the need to avoid potential negative externalities that could arise from a decentralized wage-setting process in highly unionized economies. In this paper, we put forth the novel idea that the main externality is a fiscal one, and assess, with the help of a simple equilibrium model, whether such externality can indeed lead to the establishment of centralized negotiations. Our model explains the collapse of centralization in terms of technological change, which is explicitly modeled using recent empirical evidence. The model we present abstracts from a number of institutions an historical developments that might have played an important role in the determination of the wage-setting process. Hence, this paper intends neither to challenge previous theories nor to offer a revisionist view of modern Scandinavian economic history. Our aim is simply to introduce, and assess, a new hypothesis in the debate on the rise and fall of centralized wage bargaining.

Even though the model we propose is rather stylized, especially concerning issues noncentral to our arguments, it captures well the main tensions we think shape the feedback 
from public insurance and technology to the wage-bargaining arrangement, a feedback that will help us explain the rise and fall of centralization. The main ingredients of our theory are: government-funded, union-administered unemployment benefits, progressive direct taxation, and technological progress. Both the setup of centralization and its collapse can be accounted for in terms of the interplay of fiscal and technological links among different types of workers. Fiscal links are created by the unemployment benefits program, and technological links by the production process.

Our modeling of the ingredients mentioned above, and their role in shaping the links among workers, is the following. Union-administered unemployment benefits (Ghent system) leads to high unionization rates. ${ }^{1}$ Hence, we will assume full unionization. The unions' role is to disburse benefits and negotiate wages in order to maximize the affiliated worker's net income. Under government-funded benefits, when a union negotiates in a decentralized manner it imposes an externality on other unions, as it transfers part of the burden of financing benefits for its own unemployed to the rest of the economy. That is, a worker's net income depends not only on the wage his union negotiates, but also on the wages negotiated by all other unions in the economy. This creates fiscal and benefit externalities among unions when negotiation is decentralized.

Workers are also linked by the production process, and technical change shapes the nature of that link. Our modeling of the production process and its evolution during the postwar period is based on Greenwood, Hercowitz and Krusell (1997). Technological progress is investment specific, as it is embodied in new capital equipment (i.e., in order to realize the benefits of technological progress firms must invest in new equipment). Following this approach to technological progress Krusell, Ohanian, Ríos-Rull and Violante (2000) and Lindquist (2005) estimate an aggregate production function for the U.S. and the Swedish economies, respectively. They find evidence for the existence of equipmentskill complementarity. The combination of equipment-specific technical progress and equipment-skill complementarity yields an increase in the spread of labor productivity across workers.

In a calibrated version of our model, we show that the interplay of the two linkages

\footnotetext{
${ }^{1}$ Unionization rates in countries with a Ghent system, like Sweden, are above 90\%, and, contrary to the US, the UK and other continental European countries have not shown a tendency to decline. (See Clasen and Viebrock (2008) for a study of labor union membership and the Ghent system.)
} 
— fiscal and technological — can account both for the initial setup of centralized wage bargaining and for its subsequent collapse. The intuition for this result can be outlined as follows. Under the pre-80's production technology, with expensive and scarce capital equipment, high-skilled and low-skilled workers are productivity-wise fairly close. Therefore, the fiscal externalities created by the program of unemployment benefits when bargaining is decentralized open a route to multiple equilibria and hence to coordination failures. Since coordination failures can impinge upon unions' income, there are systems of expectations that support centralized bargaining as an equilibrium of the pre-80's economy. Thus, according to our theory, the rise of centralization was a response to the need to internalize the fiscal spillovers of wage bargaining. The basic principle underlying this result is that a generous and progressive system of public insurance may be a source of macroeconomic instability, which induces economic agents - labor unions in this case - to respond by creating new institutions in order to mitigate the implied volatility on their income levels.

The fall of centralization can be understood as the result of technological progress, which brings down the price of equipment and, holding fiscal variables fixed, increases the productivity gap across skills. This increase in productivity heterogeneity among workers removes the possibility of coordination failures, and, consequently, the existence of rational expectations supporting centralized bargaining. ${ }^{2}$ Our explanation for the fall of centralization abstracts thus from issues of wage solidarity, and/or changes in the relative strength of different workers within the union federation. Our analysis is also silent on the relationship between the wage-setting arrangement and industry sectoral composition. [For an analysis of the effects of centralized bargaining on the industry distribution of employment see Davis and Henrekson (2005).]

The paper is organized as follows. Section 2 contains a brief review of the related literature. In Section 3 we discuss some evidence of the rise and fall of centralization, and review some institutional features of the Scandinavian benefits program. In Section 4 we present the model and define the equilibrium. In Section 5 we parameterize and calibrate the model, and present our main results. Section 6 draws the main conclusions.

\footnotetext{
${ }^{2}$ The role of heterogeneity in eliminating equilibrium multiplicity, and thus the possibility of coordination failures, has been amply established in the literature [see e.g. Morris and Shin (2003)].
} 


\section{Related Literature}

Empirical work on the relationship between wage bargaining arrangements and macroeconomic performance has shown the importance of the wage-setting process in determining aggregate economic variables. A first strand of this literature has focused on ascertaining the effects on unemployment rates [see, e.g., Blanchard and Wolfers (2000) and Daveri and Tabellini (2000)]. These studies have found, using panel data for the OECD countries, that highly centralized wage bargaining leads to lower unemployment. These results have led many authors to believe that Scandinavian countries were able to maintain low levels of unemployment in the 70's - while other European countries started to see their unemployment rates climb to two-digit figures - because of their highly centralized wagebargaining arrangements. A second strand of the literature has focused on the relationship between centralization and competitiveness [see, e.g., Alesina and Perotti (1997) and Summers, Gruber and Vergara (1993)]. These studies have found that the effects of increases in labor taxes on labor costs are lower in countries with highly centralized labor markets than in countries with intermediate levels of centralization. These results have led to the conclusion that centralization has helped Scandinavian countries to improve their international competitiveness.

Most explanations of the rise and fall of centralized bargaining, including this paper, share a common basic idea: decentralized wage bargaining imposes some type of externality, which, in fully unionized economies, can be internalized through centralized wage bargaining. When the gains from such an internalization are positive, centralization will emerge as the wage-setting arrangement, otherwise decentralization will prevail.

In a pioneering and influential paper, Calmfors and Driffill (1988) put forward the idea of price inflation externalities in the process of wage setting -i.e., claims for nominal wage increases by one union bring higher prices for the whole economy. These authors study the relationship between the centralization of wage bargaining and macroeconomic performance, and find the, by now well-known, hump-shaped relation between centralization and unemployment. Building upon the Calmfors and Driffill price inflation externality, a number of papers [e.g., Cukierman and Lippi (1999, 2001), Iversen (1998), Soskice and Iversen (1998) and Velasco and Guzzo (1999)] added to the model a role for monetary policy by introducing a central bank. The explanations for the rise and fall of centralization 
that seem to emerge from this literature depend on the goal assigned to central banks, either as inflation or unemployment fighters.

On the one hand, if the goal of the national central bank is to control national inflation, it will adopt non-accommodating, restrictive monetary policies as a response to unions' claims for higher nominal wages. When such a central bank is sovereign in setting monetary policy, centralized wage bargaining is a means for labor unions to anticipate the central bank's response to wage increases and, therefore, centralization may arise as the desirable wage-setting arrangement. With the advent of the European Monetary Union, national central banks lost part of their independence to set monetary policy in favor of the European Central Bank, whose target is European inflation. Consequently, national centralized bargaining becomes an invalid means to internalize the interest rate effects of union wage claims, thus explaining its collapse.

On the other hand, if the goal of the national central bank is unemployment, it will adopt accommodating, inflationary monetary policies as a response to higher nominal wages. The collapse of centralization in this case is explained as a consequence of globalization: increased international capital mobility hinders the use of inflationary monetary policies, and thus reduces the anticipatory gains of centralized bargaining. As an explanation for the rise and fall of centralization, this inflation externality mechanism has been subject to criticism. Bleaney (1996) concludes that there is no evidence of a causal relationship between monetary policy and centralization.

Our paper is also related to Freeman and Gibbons (1995). We depart from these authors in two important respects. First, contrary to our fiscal externality, these authors see the threat of price inflation as the main reason for centralization. Regarding its collapse, they point out two main reasons, "a reduction in the importance of controlling inflation through centralized negotiations", and, second, "the more heterogenous the groups covered by the central agreement, the more likely some groups will [...] consider a defect strategy." In their framework the meaning of heterogeneity is, however, vague, and it is modeled as a shift parameter known to firms and unions, but unknown to the central federation. They interpret this parameter as a productivity or price shock. We depart by modeling technological progress explicitly. We use recent evidence on the extent of equipmentspecific technical change and on equipment-skill complementarities. Another difference 
with respect to Freeman and Gibbons (1995) is that we view the cost of centralization as a distributional one, arising from the tension between high- and low-skilled workers, instead of the inefficiency costs arising from asymmetric information as postulated by these authors. Even though our framework is different from theirs, both in the modeling of the labor market, and in the role played by labor unions and their union federation, some implications are, however, similar.

Our analysis shares important similarities with Acemoglu, Aghion and Violante (2001). These authors abstract from issues related to the centralization of wage bargaining, and focus on the decline in unionization rates in the US and the UK. They argue that skillbiased technical change causes deunionization because it increases the relative productivity of high-skilled workers, and, hence, weakens their incentives to remain in a union that compresses wages.

Alexopoulos and Cohen (2003) depart from the internalization argument outlined above and propose an explanation for the rise and fall of centralization based on a reallocation hypothesis. These authors argue that centralization was a means to help increase the supply of labor to the growing, export-oriented firms. They point to a decrease in interunion solidarity as the main cause of the collapse in centralization.

Finally, our work is also related to the work of Delacroix (2006). This author studies the contribution of institutional differences (union presence, collective bargaining and centralization) to the differential in unemployment between Europe and the U.S. With this aim, the author presents a model where these institutions are exogenous and can be varied so that their impact on the unemployment rate can be assessed quantitatively. It is found that unemployment increases with collective bargaining coverage and decreases with centralization.

\section{Some Evidence on The Rise and Fall of Centralization}

The rise and fall of centralized wage bargaining has been extensively reported in the literature [see Lundberg (1985) for an early contribution]. In more recent years, the construction of indexes of centralization has shed new light on issues such as the crosscountry disparity in centralization, and its decline in countries where centralization was 
the long-standing wage-setting arrangement.

In order to show that the decline in centralization did actually imply a loss of ability to internalize macroeconomic constraints -i.e., that it was not compensated by other forms of coordination,-- we also present indexes of coordination in wage bargaining, as centralization and coordination in wage bargaining are not equivalent concepts. Centralization describes the locus of the formal structure of wage bargaining. Typically, three broad levels are distinguished: national, industry and firm-level bargaining. Coordination refers instead to the degree of consensus between bargaining partners, or in other words, to the degree of intentional harmonization in the wage-setting process. Coordination can thus be the result of communication and guidance between bargaining units without calling for the centralization of negotiations. The evidence presented in this section shows an unambiguous tendency towards less centralization and less coordination, especially in those countries with high initial levels in both.

The most widely used index of centralization in wage bargaining is the one constructed by Iversen (1999). His index ranges from 0 to 1 , where 1 corresponds to full centralization. The index combines a measure of the level of bargaining (centralized, intermediate and decentralized) with a measure of union concentration. The index also takes into account the degree of enforceability of wage agreements, that is the ability of lower-level bargainers to elude the agreement. The index covers 15 OECD countries from 1973 to 1993. Table 1 below presents the evolution of centralization for the three countries with the highest centralization scores in the early 70's: Denmark, Finland and Sweden. During the twentyyear period 1973-1993, centralization in these countries declined by almost a $50 \%$. Other countries $^{3}$ with moderate levels of centralization in the 70's also experienced a significant falloff during the same period; an example is the UK, whose centralization scores are shown in Table 1. Finally, and in order to help assess the extent of centralization in these European countries in the early 70's, we also present the index for the US.

\footnotetext{
${ }^{3}$ Among these countries are Austria, Belgium and Germany.
} 
TABLE 1-AN INDEX OF CENTRALIZATION IN WAGE BARGAINING

\begin{tabular}{lccc}
\hline \hline & $1973-79$ & $1980-86$ & $1987-93$ \\
\hline Denmark & 0.62 & 0.42 & 0.33 \\
Finland & 0.47 & 0.4 & 0.35 \\
Sweden & 0.6 & 0.5 & 0.35 \\
United Kingdom & 0.26 & 0.12 & 0.12 \\
United States & 0.07 & 0.07 & 0.07 \\
\hline \hline
\end{tabular}

Source: Iversen (1999)

Kenworthy (2001) presents an index of coordination in wage bargaining. Besides formal bargaining centralization, the index considers other ways of achieving coordination such as informal centralization and pattern-setting. The index distinguishes 5 categories, ordered by their increasing level of coordination: 1 corresponds to fragmented wage bargaining confined to individual firms or plants, and 5 corresponds to centralized bargaining by peak confederations with perfect enforceability. Table 2 presents this coordination index.

TABLE 2-AN INDEX OF COORDINATION IN WAGE BARGAINING

\begin{tabular}{lccc}
\hline \hline & $1973-79$ & $1980-86$ & $1987-93$ \\
\hline Denmark & 5 & 3.85 & 3 \\
Finland & 4 & 3.6 & 3.25 \\
Sweden & 5 & 4 & 3.4 \\
United Kingdom & 4 & 1 & 1 \\
United States & 1.5 & 1 & 1 \\
\hline \hline
\end{tabular}

Source: Kenworthy (2001).

A combined index of centralization and coordination in wage bargaining is presented in Calmfors (2001) [the index is based on work by Visser (2000)]. This index includes measures of the level of negotiation, and of the share of union members organized by the federation. The index presents averages for the periods 1973-77, 1983-87 and 1993-97. 
TABLE 3-A COMBINED INDEX OF CENTRALIZATION AND COORDINATION

\begin{tabular}{lccc}
\hline \hline & $1973-77$ & $1983-87$ & $1993-97$ \\
\hline Denmark & 0.64 & 0.47 & 0.34 \\
Finland & 0.64 & 0.58 & 0.47 \\
Sweden & 0.75 & 0.49 & 0.39 \\
United Kingdom & 0.37 & 0.18 & 0.14 \\
\hline \hline Source: Calmfors (2001). Information for the US is not reported.
\end{tabular}

We find it convenient to review some events of the first postwar years which marked the rise of centralization. We restrict our attention here to the case of Sweden, since other countries where centralization was high, e.g. Denmark and Finland, present striking similarities with the Swedish case. We briefly describe the main building blocks of the Swedish unemployment program, and then argue that some of the features of this program played a key role in the rise of centralized wage negotiations.

Among all the policies adopted in the first years of the postwar period, those related to fiscal and social issues were at the forefront. Indeed, the construction of the welfare state was unarguably the flagship of the so-called Swedish model. These policies built on two main pillars: highly progressive direct taxation, and enlargement of social insurance programs. The latter included a generous system of union-administered, progressive unemployment benefits financed by the government, known as the Ghent system. In Sweden, cash benefits for the unemployed are disbursed by forty societies that administer unemployment funds. Each society is ordinarily affiliated with one or more labor unions. To apply for income-related unemployment benefits from a society, a worker must be affiliated with a union for at least one year before becoming unemployed. Therefore, and not surprisingly, in countries with a Ghent system (Sweden, Denmark, Finland) unionization rates climbed and remained at rates in the order of $90 \%$. Funds for the unemployment benefits program are provided by the government using a pay-as-you-go financing system. Labor unions' contribution is purely symbolic amounting only to an average of six percent of the whole program. With pay-as-you-go financing, tax rates on factor incomes are set such that current tax revenues equal current benefits. ${ }^{4}$

\footnotetext{
${ }^{4}$ In the late 1990's Scandinavian economies started a debate on reforming the financing of unemployment benefits. In Finland, buffer funding of unemployment benefits was discussed. Contributions to the
} 
Within the context of this institutional arrangement, Swedish unions' and employers' federations held the first centralized wage negotiations in the early fifties. ${ }^{5}$ Centralization went on almost uninterruptedly until the early 80's. We argue in this paper that two features of the Ghent system, namely, the workers' affiliation requirement and the public, pay-as-you-go funding of benefits, set necessary conditions for the centralization of wage bargaining. The first by leading to full unionization, and the second by creating fiscal externalities among labor unions under decentralized wage bargaining.

By the time Scandinavian economies were implementing a Ghent program of unemployment benefits, the UK and most non-Scandinavian European countries had already abandoned the Ghent system to adopt compulsory ones. In compulsory systems unemployment benefits are government-administered. Workers collect payments directly from the government without conditioning on affiliation with a labor union. As a result, unionization rates in non-Scandinavian economies hardly ever reached $50 \%$.

\section{The Model}

In this section we present a model of frictional unemployment and define the equilibrium under different levels of centralization in wage bargaining. We consider an economy with two types of workers: high-skilled $(s)$ and low-skilled $(u)$. Since our emphasis here is on the externalities generated by the financing of unemployment benefits, and on the production process, we abstract from other labor market externalities by assuming perfectly segmented labor markets. That is, high- and low-skilled workers do not congest each other when searching for a job. If we denote by $h_{j, t}$ the number of workers of type $j$ searching for a job at time $t$, and by $v_{j, t}$ the number of vacancies open for type- $j$ workers at time $t$, for $j=s, u$, then, the total number of matches is given by

$$
M_{j, t}=\mathcal{M}\left(v_{j, t}, h_{j, t}\right),
$$

unemployment program could exceed outlays in some periods and thus the buffer stock would be created. In Sweden, the Swedish Confederation of Professional Associations, SACO, (a federation of labor unions for high-skilled workers), made a proposal to run its own benefits program, which, ultimately, amounts to a proposal to untie unemployment contributions from general taxation and thus to remove fiscal links among unions.

${ }^{5}$ Actually, unions' and employers' federations had already met in 1938, but only to reach agreements concerning procedures for settling disputes and work safety. 
where $\mathcal{M}(\cdot, \cdot)$ has the standard properties of a matching function, i.e., it is increasing in the number of vacancies, $v_{j}$, and searchers, $h_{j}$, is concave in both arguments and linearly homogeneous.

Unions There is a continuum of workers of measure one. Let $x_{j}$ denote the measure of workers of type $j$, for $j=s, u$. Since unemployment benefits are union-administered, we can assume that all workers are affiliated with labor unions. Unions are risk neutral, and workers choose the union according to their type. There are $N_{j}$ unions of workers of type $j$. A worker can be in one of the following three situations: 1) employed $(e), 2)$ unemployed and entitled to unemployment benefits $(u b)$, or 3) unemployed and not entitled to benefits, in which case the worker enters the welfare program $(u w)$. The number of hours worked by an employed worker is fixed and normalized to one. Thus, an employed union member's net income at time $t$ is $y_{j, t}^{e}=\omega_{j, t}-\tau_{t}\left(\omega_{j, t}-d\right)$, where $\omega_{j, t}$ is the wage rate, $\tau_{t}$ is the tax rate, and $d>0$ is a personal deduction. The personal deduction is included in order to introduce progressivity in the tax scheme. An unemployed union member's net income, if entitled to unemployment benefits, is $y_{j, t}^{u b}=\Phi_{t}\left(\omega_{j, t}+\varsigma\right)-\tau_{t}\left[\Phi_{t}\left(\omega_{j, t}+\varsigma\right)-d\right]$, where $\Phi_{t}$ and $\varsigma \geq 0$ determine the generosity and progressivity of the unemployment benefit program. $\varsigma$ is a parameter that pins down the progressivity of benefits; for $\varsigma=0$ the entitled unemployed receives a proportion $\Phi_{t}$ of the wage rate. If the unemployed worker is not entitled to unemployment benefits, he will receive a lump sum $B>0$ from the welfare program, which leaves the net income of unemployed workers on welfare at $y_{t}^{u w}=B-\tau_{t}(B-d)$. (We are implicitly assuming that the unemployed's gross income, either on benefits or welfare, is at least as large as $d$.)

The transition from unemployment to employment and vice versa is as follows. At the end of a period all jobs are destroyed. At the beginning of the next period all workers search for a job at the cost $\kappa>0$. Those who are matched with a vacancy, and affiliated with a union whose wage bargaining ended in agreement, become employed. Remaining workers become unemployed.

Hence, the expected pre-matching after-tax income of a typical union worker of type $j$ is given by,

$$
y_{j, t}=m_{j, t} y_{j, t}^{e}+\left(1-m_{j, t}\right)\left[(1-\psi) y_{j, t}^{u b}+\psi y^{u w}\right] \quad \text { for } j=s, u
$$

where $m_{j, t}$ denotes the matching rate for workers of type $j ; \psi$ is the rate that governs 
eligibility for unemployment benefits. That is, $\psi$ is the exit rate from the unemployment benefit program. Thus, conditional on remaining unemployed, an average unemployed worker receives unemployment benefits for $1 / \psi$ periods. In order to simplify notation we will use $\phi_{t}$ to denote the product $\Phi_{t}(1-\psi)$ whenever we find it convenient.

A typical union of type- $j$ workers will choose to hold centralized wage negotiations whenever it yields a higher $y_{j, t}$ than under decentralized bargaining. The analysis of wage determination under each of these two bargaining arrangements is presented below.

Firms There is a continuum of firms producing an aggregate homogeneous good. The technology is constant returns to scale in high- and low-skilled labor, capital structures, $k_{s t}$, and capital equipment, $k_{e q}$. The assumption of constant returns to scale renders constant capital-employment and vacancies-employment ratios across firms. Thus, we can write the maximization problem of a representative firm as,

$$
\pi_{t}=\max _{v_{s, t}, v_{u, t}, k_{s t, t}, k_{e q, t}}\left\{F\left(k_{s t, t}, k_{e q, t}, n_{s, t}, n_{u, t}\right)-\sum_{j=s, u}\left[\omega_{j, t} n_{j, t}+a_{j}\left(v_{j, t}\right)\right]-\sum_{i=s t, e q} r_{i, t} k_{i, t}\right\} .
$$

Employment levels are given by $n_{j, t}=\mu_{j, t} v_{j, t}$, for $j=s$, $u$, where $\mu_{j, t}$ denotes the matching rate for a vacancy of type $j$, which is taken as given by the firm when choosing the number of vacancies; $r_{s t, t}$ and $r_{e q, t}$ denote the rental prices of structures and equipment, respectively; and $a_{j}\left(v_{j, t}\right)$ is a convex vacancy cost function whose particular functional form is presented below. So far, we only impose that $F$ satisfies the standard assumptions of concavity, differentiability and homogeneity of degree one. Further assumptions on the elasticities of substitution between equipment and each type of labor will be imposed in Section 5 .

The timing of actions within a time period is: firms open vacancies, then wages are negotiated and capital is rented. Hence, as will become clearer in the next subsections, the problem of the individual firm depends critically on whether wage bargaining is decentralized or centralized. In the former scenario the firm is in charge of its own wage negotiations, and, therefore, it does not take wage rates as given when opening vacancies, but it anticipates the effects of its own hiring on negotiated wages. Thus, in problem (4.3), the firm correctly anticipates wage functions $\omega_{j}\left(n_{s, t}, n_{u, t}\right)$, for $j=s, u$. This is an application of so-called intra-firm bargaining, first proposed by Stole and Zwiebel (1996), and then used by Cahuc and Wasmer (2001), Cahuc, Marque and Wasmer (2008) and 
Rotemberg (2006), among others, within the framework of search-and-matching models. ${ }^{6}$ On the other hand, when bargaining is centralized, the individual firm takes wages as given as these will be negotiated by the employers' federation.

Capital stocks can be adjusted at no cost. Firms' capital demands are obtained by equating rental prices to the respective marginal productivities,

$$
F_{k_{i, t}}=r_{i, t} \quad \text { for } \quad i=s t, e q
$$

where $F_{k_{s t, t}}$ and $F_{k_{e q, t}}$ denote the derivatives of the production function with respect to $k_{s t, t}$ and $k_{e q, t}$, respectively.

Capitalists The owners of capital (structures and equipment) and the firms are called capitalists. We also assume that they are risk neutral, and their only decision is to split current income between consumption and investment. Their objective is to maximize discounted lifetime consumption of the aggregate good. Capitalists' income is made up of capital income and firms' profits. Factor incomes are subject to taxation at the rate $\tau_{t}$, net of the personal deduction $d$. Thus, capitalists' time-t consumption, $c_{t}$, is determined by the budget constraint,

$$
c_{t}+i_{s t, t}+i_{e q, t}=\left(1-\tau_{t}\right)\left[r_{s t, t} k_{s t, t}+r_{e q, t} k_{e q, t}\right]+\tau_{t} d+\pi_{t},
$$

where $i_{s t, t}$ and $i_{e q, t}$ denote gross investment in structures and equipment, respectively, and $\pi_{t}$ denotes firms' profits. Structures depreciate at the rate $\delta_{s t}$, and equipment at the rate $\delta_{e q}$. Our assumption of equipment-specific technical change implies that one unit of the aggregate good invested in equipment increases its stock by $q$ units. That is, the law of motion for capital equipment is,

$$
k_{e q, t+1}=\left(1-\delta_{e q}\right) k_{e q, t}+i_{e q, t} q .
$$

On the contrary, one unit of the aggregate good invested in structures increases its stock by one unit. Thus, factor $q$ represents the level of technology for producing capital equipment, and an increase in $q$ is interpreted as equipment-specific technical progress. This particular modeling was first proposed by Greenwood, Hercowitz and Krusell (1997) in order to assess

\footnotetext{
${ }^{6}$ It should be noted that the Stole-Zwiebel's effect is not key for our results below. In an early version of our paper we solved the decentralized bargaining problem abstracting entirely from this effect and found the same qualitative results.
} 
the role of sector-specific technical change in generating postwar U.S. growth. Since $1 / q$ is the relative price of equipment, the rate of equipment-specific technological progress can be derived from the price series. It has been widely reported that $q$ increased during the postwar period in most industrialized countries. For example, in the U.S. economy the average annual rate of increase during the postwar period is well above $3 \%$. Here, we will focus our attention on two dates and, therefore, will consider two different values for $q$.

Under the assumptions stated above it is straightforward to show that the optimal investment policy for the capitalists calls for,

$$
\left(1-\tau_{t}\right) r_{s t, t}-\delta_{s t}=\left(1-\tau_{t}\right) q r_{e q, t}-\delta_{e q}=\frac{1}{\beta}-1,
$$

where $0<\beta<1$ is the discount factor.

The Unemployment Benefits and Welfare Program Unemployment funding, including unemployment benefits and welfare, is provided by the government, which is assumed to balance the program's budget every period. Under these assumptions we can write the unemployment program's budget constraint as,

$$
\tau_{t} T_{t}=(1-\psi) \sum_{j=s, u}\left(x_{j}-n_{j, t}\right) \Phi_{t}\left(\omega_{j, t}+\varsigma\right)+\psi \sum_{j=s, u}\left(x_{j}-n_{j, t}\right) B
$$

where $T_{t}$ denotes the tax base and is given by,

$$
\begin{array}{r}
T_{t}=\sum_{j=s, u}\left(n_{j, t}\left(\omega_{j, t}-d\right)+(1-\psi)\left(x_{j}-n_{j, t}\right)\left(\Phi_{t}\left(\omega_{j, t}+\varsigma\right)-d\right)+\psi\left(x_{j}-n_{j, t}\right)(B-d)\right)+ \\
+\sum_{i=s t, e q} r_{i, t} k_{i, t}-d .
\end{array}
$$

The right-hand side of equation (4.8) represents total outlays of the program, namely, unemployment benefits to all entitled unemployed workers plus welfare payments to those not entitled to benefits. The public financing of unemployment benefits and welfare, along with the assumption of a balanced budget, implies that the tax rate is an endogenous variable which depends on the wage rates and employment levels prevailing in the whole economy.

Unemployment benefits are set by the government after wages have been bargained. We think of the government as using unemployment benefits to redistribute income. Government's preferences are represented by a generalized utilitarian social welfare function 
over net incomes of all agents in the economy: capitalists, employed workers, unemployed workers on benefits and the unemployed on welfare. Thus, subject to (4.8), the government sets $\Phi_{t}$ in order to maximize

$$
S W=\left(\left(y_{t}^{c}\right)^{\gamma}+\sum_{j=s, u} n_{j, t}\left(y_{j, t}^{e}\right)^{\gamma}+(1-\psi)\left(x_{j}-n_{j, t}\right)\left(y_{j, t}^{u b}\right)^{\gamma}+\psi\left(x_{j}-n_{j, t}\right)\left(y^{u w}\right)^{\gamma}\right)^{\frac{1}{\gamma}}
$$

where $y_{t}^{c}$ denotes capitalists' net income, and $\gamma \leq 1$ determines the government's attitude towards inequality, with $\gamma=1$ corresponding to an inequality-insensitive government. When bargaining is centralized, employers' and unions' federations anticipate the effects of wages on both unemployment benefits, $\Phi_{t}$, and taxes, $\tau_{t}$. When bargaining is decentralized, individual unions and firms take both policy variables as given.

The next subsections present the equilibrium under decentralized and centralized bargaining. For notational convenience we will drop the time subscript for the remaining of the paper. Our assumptions imply that the model has no transitional dynamics.

\subsection{The Decentralized Bargaining Equilibrium}

In this subsection we characterize the decentralized bargaining equilibrium. As was explained above, when opening vacancies firms anticipate the effects of hiring on wages. Thus, first-order conditions for vacancies are,

$$
\left[F_{n_{j}}-\omega_{j}-\frac{\partial \omega_{s}}{\partial n_{j}}\left(n_{s}, n_{u}\right) n_{s,}-\frac{\partial \omega_{u}}{\partial n_{j}}\left(n_{s}, n_{u}\right) n_{u}\right] \mu_{j}=a_{j}^{\prime}\left(v_{j}\right) \quad \text { for } \quad j=s, u,
$$

where $F_{n_{j}}$ denotes the derivative of the production function with respect to $n_{j} ; \partial \omega_{l} / \partial n_{j}$ denotes the partial derivative of the wage for workers of type $l$ with respect to the firm's employment level of workers of type $j$; and $a_{j}^{\prime}\left(v_{j}\right)$ is the derivative of the vacancy cost function. These first-order conditions establish that the marginal cost of a vacancy equals its marginal return. It becomes clear from equation (4.10) that when assessing the return of a new vacancy of type $j$ the firm weighs the effects of hiring on wages, as captured by the last two terms inside the square brackets.

The decentralized wage negotiations that take place after matching proceed as follows. A union is assumed to engage in wage bargaining on behalf of its affiliated workers with the firm they were matched with. We denote by $z_{j}^{i}$ the number of workers matched with 
the firm that are affiliated with union $i$ of type- $j$ workers. As in Rotemberg (2006), we adopt the simplifying assumption that unions negotiate simultaneously, each with a separate representative of the firm. Furthermore, bargaining pairs assume, at the time of bargaining, that the firm will reach agreements with all other unions. That is, the firm representative negotiating with union $i$ of type- $j$ workers fails to see the consequences on other unions' wages of not reaching an agreement. On the other hand, unions bargain without coordinating wage claims, and taking policy variables — taxes and benefits - as given.

We follow the literature on search and matching and assume that wages are the solution to Nash-bargaining problems. Income values of agreement to unions and firms are as follows. The net income value to a union $i$ of type $j$ of having $z_{j}^{i}$ workers employed at the wage $\omega_{j}$, is,

$$
\begin{array}{r}
W_{j}^{i}-U_{j}^{i}=z_{j}^{i}\left[\omega_{j}-\tau\left(\omega_{j}-d\right)\right]-z_{j}^{i}\left[(1-\psi)\left(\Phi\left(\omega_{j}+\varsigma\right)-\tau\left(\Phi\left(\omega_{j}+\varsigma\right)-d\right)\right)+\right. \\
+\psi(B-\tau(B-d))]
\end{array}
$$

which is the difference between net income from employment - the first expression on the right-hand side - and net income from the union's outside option, unemployment - the second expression on the right-hand side.

For a firm, the net income value of employing $z_{j}^{i}$ workers at wage $\omega_{j}$, anticipating that all other remaining workers matched with the firm will be employed, is,

$$
J_{j}^{i}=F-F^{-z_{j}^{i}}-\omega_{j} z_{j}^{i}-\left(k_{s t}-k_{s t}^{-z_{j}^{i}}\right) r_{s t}-\left(k_{e q}-k_{e q}^{-z_{j}^{i}}\right) r_{e q}
$$

where $F$ denotes firm's production when all matched workers are employed; $F^{-z_{j}^{i}}$ is firm's production when all but the $z_{j}^{i}$ workers affiliated with union $i$ are employed; likewise $k_{s t}^{-z_{j}^{i}}$ and $k_{e q}^{-z_{j}^{i}}$ denote, respectively, firm's demand for structures and equipment in case of disagreement with union $i$.

Union i's wages are hence given by,

$$
\omega_{j}^{i}=\operatorname{argmax}_{\omega_{j}}\left(W_{j}^{i}-U_{j}^{i}\right)^{p}\left(J_{j}^{i}\right)^{1-p},
$$

where $p$ denotes the bargaining power of the union. The first-order condition to this maximization problem is $(1-p)\left(W_{j}^{i}-U_{j}^{i}\right) J_{j}^{\prime i}+p J_{j}^{i}\left(W_{j}^{\prime i}-U_{j}^{\prime i}\right)=0$, where $J_{j}^{\prime i}, W_{j}^{\prime i}$, and 
$U_{j}^{\prime i}$ denote the corresponding derivatives with respect to $\omega_{j}$. Using the above values of employment for the union and the firm, and the first-order condition to maximization problem (4.13), we can derive the wage to union $i$ 's workers as a function of the firm's employment levels,

$$
\omega_{j}^{i}\left(n_{s}, n_{u}\right)=p\left[\frac{F-F^{-z_{j}^{i}}-\left(k_{s t}-k_{s t}^{-z_{j}^{i}}\right) r_{s t}-\left(k_{e q}-k_{e q}^{-z_{j}^{i}}\right) r_{e q}}{z_{j}^{i}}\right]+(1-p) \frac{\phi \varsigma+\psi B}{1-\phi} .
$$

We will focus on symmetric equilibria in which all unions within each skill group have the same size, i.e., $z_{j}^{i}=n_{j} / N_{j}$.

Definition A decentralized bargaining equilibrium (DBE) is a set of sequences for rental prices of capitals, $\left\{r_{s t}, r_{e q}\right\}$, employment levels, $\left\{n_{s}, n_{u}\right\}$, capital stocks $\left\{k_{s t}, k_{e q}\right\}$, vacancies $\left\{v_{s}, v_{u}\right\}$, matching rates for vacancies $\left\{\mu_{s}, \mu_{u}\right\}$, matching rates for workers $\left\{m_{s}, m_{u}\right\}$, the tax rate $\{\tau\}$, unemployment benefits, $\{\Phi\}$, and a pair of wage functions $\omega_{s}\left(n_{s}, n_{u}\right)$ and $\omega_{u}\left(n_{s}, n_{u}\right)$, such that,

(i) Taking rental prices, wage functions and matching rates as given, $\left\{k_{s t}, k_{e q}\right\}$, and $\left\{v_{s}, v_{u}\right\}$ solve the firms' maximization problem, and $n_{j}=\mu_{j} v_{j}$, for $j=s, u$.

(ii) Taking tax rates and rental prices as given, $\left\{k_{s t}, k_{e q}\right\}$ maximize capitalists' lifetime utility.

(iii) Taking unemployment benefits as given, wage functions are the Nash solution to uncoordinated bargaining problems.

(iv) Matching rates are given by the matching function, i.e., $\mu_{j}=M_{j} / v_{j}$, and $m_{j}=$ $M_{j} / x_{j}$, for $j=s, u$.

(v) $\{\Phi\}$ solves the government's maximization problem, and the budget constraint of the unemployment benefit program holds.

(vi) The following participation constraints are satisfied: workers' pre-matching net incomes are at least as high as search costs, i.e., $y_{j} \geq \kappa$, for $j=s, u$.

The possibility of multiple equilibria stems from the externalities generated by the unemployment benefits program. From the two wage equations (4.14), it is clear that 
the wage rate for a union- $j$ 's worker depends on benefits. Since policy variables are determined in equilibrium by all wages bargained in the economy, there is room for multiple expectational equilibria. Thus, there may be multiple values for $\tau_{t}$ and $\Phi_{t}$ such that when they are expected to prevail in equilibrium by all unions and firms, they also solve the government's maximization problem at the wages satisfying (4.14). ${ }^{7}$ It is also evident from (4.14) that the multiplicity of decentralized equilibria depends crucially on two main factors. First, the strength of the fiscal externalities -i.e., the extent to which fiscal and benefit variables affect negotiated wages. The last term in the wage equations shows that the generosity and progressivity of unemployment benefits, welfare payments and the eligibility to benefits are key determinants of the fiscal externalities. Second, the productivity gap across workers, as captured by $F-F^{-z_{j}^{i}}$ for $j=s, u$, in the first terms of the wage equations.

\subsection{The Centralized Bargaining Equilibrium}

Under centralized, national wage bargaining, all workers, both high- and low-skilled, employed and unemployed, are represented in a single bargaining table. Wages to all matched workers are set simultaneously, taking into account the effects on both taxes and unemployment benefits. ${ }^{8}$

\footnotetext{
${ }^{7}$ The existence of multiple equilibria under a balanced-budget rule is typically referred to as a type of Laffer curve. Den Haan (2007) and Rocheteau (1999) have shown, within a search-and-matching model, that a balanced-budget rule can generate multiple long-run equilibria with different unemployment rates. These authors use a different setup than ours and abstract from issues of centralization/coordination in wage bargaining. Den Haan (2007) presents a model where unemployment benefits per unemployed worker and other government expenditures are exogenously fixed. The income tax rate must then adjust so that the balanced-budget rule holds. The author finds multiple steady-state unemployment rates if government expenditures and unemployment benefits are high enough. In the framework of Rocheteau (1999) unemployment benefits are financed by a lump-sum tax on production. This author shows that equilibrium multiplicity is a generic property under a balanced-budget rule.

${ }^{8}$ This particular modeling of centralization is in concordance with the Swedish experience. In the Swedish economy, LO was the central workers' confederation in charge of negotiating for workers for more than three decades. In LO's web site one can read "LO is primarily an organization for coordination, research and creating public opinion. Wage bargaining and labor market insurance schemes are some of the areas for which LO is responsible for coordination. Affiliates of LO have independent status and are responsible for the administration of the unemployment insurance funds."
} 
Individual firms do not engage directly in wage negotiations, and then intra-firm bargaining does not apply. Firms take wage rates as given when opening vacancies, which renders the following first-order conditions,

$$
\left[F_{n_{j}}-\omega_{j}\right] \mu_{j}=a_{j}^{\prime}\left(v_{j}\right) \quad \text { for } \quad j=s, u
$$

Since our analysis abstracts from wage solidarity — both within and across unionsand since workers are heterogeneous - both in terms of skills and of the matching outcomewe envision two different ways of modeling the unions' federation. The first one is to assume that the encompassing unions' federation is utilitarian, seeks to maximize the sum of all workers' net incomes and engages in a two-agent bargaining with the employers' federation. Alternatively, we can model the unions' federation as being made up of coalitions of homogeneous workers, which engage in a multi-agent bargaining with the employers' federation. Since the results do not depend on which model is adopted, in this section we present the results using the latter.

The income value of having $n_{s}$ and $n_{u}$ workers employed at wages $\omega_{s}$ and $\omega_{u}$ for the different coalitions of workers and for the employers' federation are as follows. Within the coalition of unions for type- $j$ workers there are two homogeneous coalitions of sizes $M_{j}$ and $x_{j}-M_{j}$ (which in equilibrium are $n_{j}$ and $x_{j}-n_{j}$, respectively). Income values for each worker within each of the coalitions are now presented. The value to a matched worker in a union for type- $j$ workers is,

$$
W_{j}=\omega_{j}-\tau\left(\omega_{j}-d\right)
$$

The value to an unmatched union worker of type $j$ is,

$$
U_{j}=(1-\psi)\left[\Phi\left(\omega_{j}+\varsigma\right)-\tau\left(\Phi\left(\omega_{j}+\varsigma\right)-d\right)\right]+\psi[B-\tau(B-d)]
$$

The income value to the employers' federation of employing $n_{s}$ and $n_{u}$ workers at wages $\omega_{s}$ and $\omega_{u}$, respectively, is

$$
J=F\left(k_{s t}, k_{e q}, n_{s}, n_{u}\right)-\sum_{j=s, u} \omega_{j} n_{j}-\sum_{i=s t, e q} r_{i} k_{i} .
$$

The outside option to centralized bargaining, both for workers and the employers' federation, is to return to the decentralized economy where firms open vacancies according 
to eq. (4.10) and engage in wage negotiations with individual unions as described in the previous section. The value of this option to a worker in a type- $j$ union is his expected income under decentralization, which we denote by $E_{j}$, for $j=s, u$. When there are multiple decentralized bargaining equilibria, expectations are taken using subjective probabilities over those equilibria. Thus, in the event of two decentralized equilibria, $E_{j}=$ $\eta y_{j}^{e q 1}+(1-\eta) y_{j}^{e q 2}-\kappa$, where $\eta$ is the subjective probability placed on the occurrence of equilibrium $1 .^{9}$

The value to the employers' federation is given by expected firms' profits, which we denote by $\bar{J}$. For simplicity it is assumed that both federations have the same subjective probabilities on the occurrence of the two equilibria.

Wage rates in the centralized bargaining equilibrium are the solution to a Nashbargaining problem between the coalitions within type- $s$ unions, coalitions within type- $u$ unions and the employers' federation. The maximization problem is given by, ${ }^{10}$

$$
\max _{\left\{\omega_{s}, \omega_{u}\right\}}\left[\prod_{j=s, u}\left(W_{j}-E_{j}\right)^{n_{j}}\left(U_{j}-E_{j}\right)^{\left(x_{j}-n_{j}\right)}\right]^{p}(J-\bar{J})^{1-p},
$$

subject to the unemployment program's budget constraint, equation (4.8), the first-order condition to $\Phi$, and $W_{j} \geq E_{j}, U_{j} \geq E_{j}, J \geq \bar{J}$, for $j=s, u$.

Thus, by taking into account the two equations that determine policy variables, centralized bargaining internalizes the externalities stemming from the unemployment benefits program.

Definition A centralized bargaining equilibrium (CBE) is a set of sequences for rental prices of capitals, $\left\{r_{s t}, r_{e q}\right\}$, wages $\left\{\omega_{s}, \omega_{u}\right\}$, employment levels, $\left\{n_{s}, n_{u}\right\}$, capital stocks $\left\{k_{s t, t}, k_{e q, t}\right\}$, vacancies $\left\{v_{s}, v_{u}\right\}$, matching rates for vacancies $\left\{\mu_{s}, \mu_{u}\right\}$, matching rates for workers $\left\{m_{s}, m_{u}\right\}$, the tax rate $\{\tau\}$ unemployment benefits $\{\Phi\}$, and subjective probabi-

\footnotetext{
${ }^{9}$ It must be noted that if centralized negotiations fail, firms are not committed to their hiring policies and will change the number of vacancies to affect the wage that will result from the subsequent decentralized negotiations. For this reason, and in order to avoid complicating further the framework by introducing probabilities of being matched in the first round but not hired, and probabilities of being matched and hired in the second round, we assume that all workers must search again if centralized negotiations fail.

${ }^{10}$ Our modeling of negotiation between homogeneous coalitions follows Kalai (1977) by assuming that each coalition member has right to talk. For an alternative modeling of negotiation between coalitions see, for instance, Chae and Heidhues (2004).
} 
lities over the decentralized bargaining equilibria such that,

(i) Taking rental prices, wage and matching rates as given, $\left\{k_{s t}, k_{e q}\right\}$, and $\left\{v_{s}, v_{u}\right\}$ solve the firms' maximization problem and $n_{j}=\mu_{j} v_{j}$ for $j=s, u$.

(ii) Taking tax rates and rental prices as given, $\left\{k_{s t}, k_{e q}\right\}$ maximize capitalists' lifetime utility.

(iii) Wages are the Nash solution to a bargaining problem between the unions' and employers' federations with the stated subjective probabilities over the outcome of decentralized bargaining.

(iv) Matching rates are given by the matching function, i.e., $\mu_{j}=M_{j} / v_{j}$, and $m_{j}=$ $M_{j} / x_{j}$ for $j=s, u$.

(v) $\{\Phi\}$ solves the government's maximization problem, and the budget constraint of the unemployment benefit program holds.

(vi) Participation constraints are satisfied.

The decision of labor unions regarding whether to engage in centralized wage bargaining or, on the contrary, to conduct uncoordinated decentralized bargaining can be thought of in terms of a standard, infinitely repeated game, where labor unions observe the current state of the economy before they choose their actions. If we narrow the analysis by assuming Nash reversion or grim trigger strategies, and focus on pure strategy subgame perfect equilibria, then the problem can be analyzed using standard results in the literature of repeated games. ${ }^{11}$

For our problem at hand, we make the analysis even simpler. Since centrally bargained wages are enforceable, we assume that no labor union can increase the instantaneous income of the affiliated worker by deviating from cooperation within a given period. This enforceability implies that the labor unions' decision problem becomes a period-by-period problem with no intertemporal links. Moreover, since we focus on only two instances of

\footnotetext{
${ }^{11}$ Holden and Oddbjorn (1991) present a model of wage setting where unions choose to cooperate or not. In their model, if a union deviates the agreement breaks down and each union plays the one-shot Nash strategy. They assume that after a break down in cooperation there is an exogenous probability that cooperation is re-started.
} 
wage bargaining (full centralization and full decentralization), a deviation by a single union (and therefore of all unions of the same type) from centralization will cause decentralized bargaining to hold. All this, added to the fact that there are no side payments within nor across unions, simplifies the analysis of the model significantly, while retaining the tradeoffs we put forward in this paper for the rise and fall of centralized bargaining. Indeed, as will be shown below, under certain conditions on technology, there are systems of subjective probabilities over the outcome of decentralized bargaining for which centralization arises endogenously as the equilibrium bargaining arrangement. Technical change will make centralization unsustainable.

\section{The Rise and Fall of Centralized Wage Bargaining}

Under the production technology extant before the 80's, a program of unemployment benefits like the one outlined in the previous section sets the conditions for the rise of centralized wage bargaining. More specifically, we show in this section that when we calibrate our model to match some key values of the Swedish economy in 1970, the externalities from the program of unemployment benefits yield two expectational equilibria under decentralized wage bargaining. In one of these equilibria unemployment rates are high, and capital accumulation and workers' incomes are low. It is hence the existence of this bad equilibrium, along with a positive subjective probability of its occurrence, that renders centralization the prevailing wage-bargaining arrangement of the 1970 economy. In short, centralization arises as a response to the existence of multiple expectational equilibria. However, for the level of equipment-specific technology reached in the early 90's the social welfare program no longer creates the threat of a bad expectational equilibrium, and, consequently, centralized bargaining is no longer sustainable.

Parameterization We parameterize the matching process, $\mathcal{M}\left(v_{j}, h_{j}\right)$, as

$$
M_{j}=\frac{v_{j} h_{j}}{\left(v_{j}^{\rho}+h_{j}^{\rho}\right)^{\frac{1}{\rho}}} \quad \text { for } \quad j=s, u,
$$

which is an increasing and constant-returns-to-scale function in the number of vacancies and searchers. As explained by Den Haan, Ramey and Watson (2000) the main advantage of this matching function, with respect to the standard Cobb-Douglas matching function, is that matching probabilities lie between zero and one for all values of $v_{j}$ and $h_{j}$. 
We parameterize the production technology and its evolution in the postwar period assuming equipment-specific technological progress and equipment-skill complementarity. According to Greenwood, Herkowitz and Krusell (1997), the growth in production per capita experienced by the U.S. economy in the postwar period is, to a great extent, the result of equipment-specific technological progress. Krusell, Ohanian, Ríos-Rull and Violante (2000) [KORV henceforth] take this idea as a starting point and estimate an aggregate production function for the U.S. economy. Their main result is that the elasticity of substitution between equipment and high-skilled labor is lower than that between equipment and low-skilled labor: there is equipment-skill complementarity. The same result is found by Lindquist (2005) for the Swedish economy. In our model, this scenario can be represented by increases in $q$, and by assuming equipment-skill complementarity in our production function $F$.

The Krusell, Ohanian, Ríos-Rull and Violante Production Function KORV (2000) present a four-factor aggregate production function with capital equipment, capital structures, high- and low-skilled labor which allows for different elasticities of substitution among factors of production. In particular, they choose a Cobb-Douglas function over structures and a CES function of equipment, high- and low-skilled labor. The production function they estimate is,

$$
F\left(k_{s t}, k_{e q}, n_{s}, n_{u}\right)=k_{s t}^{\varphi}\left[\theta\left[\lambda k_{e q}^{\sigma}+(1-\lambda) n_{s}^{\sigma}\right]^{\alpha / \sigma}+(1-\theta) n_{u}^{\alpha}\right]^{(1-\varphi) / \alpha} .
$$

Lindquist (2005) estimates this production function for the 1967-1996 Swedish economy. Parameters $\alpha$ and $\sigma$ are of especial importance in our analysis since they determine key elasticities of substitution. The estimates for these two parameters presented by both KORV (2000) and Lindquist (2005) indicate that the elasticity of substitution between equipment and low-skilled labor is higher than that between equipment and high-skilled labor. That is, there is equipment-skill complementarity. In our notation this implies $\alpha>\sigma$.

Finally, vacancy cost functions are assumed to be quadratic in the number of vacancies, i.e., $a_{j}\left(v_{j}\right)=a_{j} v_{j}^{2}$, for $j=s, u$, where $a_{j}>0$ are parameters to be calibrated. These cost functions are a particular case of the one used by Rotemberg (2006). This author uses arguments of economies of scale to depart from a linear cost function.

Parameter values We now assign values to all parameters in the model, using both a pri- 
ori information and a number of observations for the Swedish economy to be matched. The observations that will be matched correspond to 1970, a year in which centralized bargaining was at its peak. Hence, in addition to matching selected economic variables, centralized bargaining must be chosen by all unions as the prevailing wage-setting arrangement. ${ }^{12}$

Parameters set with a priori information are the following. The measure of highskilled workers, $x_{s}$, is set at 0.05 , which is the fraction of university graduates in the labor force (see the labor force surveys, Statistics Sweden). The value of $\psi$ is set at 0.2 , which corresponds to an average eligibility for unemployment compensation of five years. The parameters in the production function are taken from the estimates for the Swedish economy by Lindquist (2005). In particular, $\sigma=-0.9$ and $\alpha=0.3$. The rate of depreciation for equipment is set at $12.5 \%$, which is the value used by Statistics Sweden for constructing the stock of capital equipment for the Swedish economy [this is the same rate found by Greenwood, Herkowitz and Krusell (1997) for the U.S. economy]. The rate of depreciation for structures is set at $5 \%$, which is the value reported by Lindquist (2005). The value of $\rho$, the parameter in the matching function, is set at 1.26 as reported by Den Haan, Ramey and Watson $(2000)^{13}$. The level of technology in the equipment-goods sector $q$ is set at 0.8 , so that the relative price of equipment over the relative price of structures in 1970 is 1.25 , as reported by Lindquist (2005). (Note that the relative price of structures has been normalized to one.) Finally, the number of unions for high-skilled workers is set at 22, which is the number of unions within the unions' confederation for professional workers, SACO. The number of unions for low-skilled workers is set at 19, which is the number of unions within LO, the unions' confederation for low-skilled labor.

The remaining ten parameters: $\kappa, a_{s}, a_{u}, \beta, \gamma, p, B, d, \varsigma$, and the subjective probability over decentralized equilibria, $\eta$, are selected so that the following observations are matched

\footnotetext{
${ }^{12}$ It should be noted that ours is not a standard calibration exercise where unknown parameter values are obtained by solving a system of non-linear equations. Economic variables in the centralized equilibrium depend on workers' pre-matching incomes in the decentralized equilibrium (or equilibria in case of multiplicity). That is, for a given list of parameter values decentralized equilibria must be computed prior to obtaining the centralized equilibrium. Consequently, we pin down unknown parameter values following an ad hoc iterative process until the centralized equilibrium matches the targeted values. Due to this procedure there might be small discrepancies between equilibrium and targeted values.

${ }^{13} \mathrm{By}$ using the same matching technology as the one calibrated for the US economy we purposely leave aside the possible effects of the wage-bargaining arrangement on the productivity of matching.
} 
by the centralized bargaining equilibrium. ( $i$ ) An unemployment rate for the high-skilled of 0.6\% (Statistics Sweden). (ii) An unemployment rate for the low-skilled of 2.7\% (Statistics Sweden). (iii) A labor's share of income of 63\%. (iv) A capital output ratio of 2.6. (v) A skill premium, defined as the university-gymnasium log wage differential, of 0.6 [this is the value for 1970 reported by Edin and Holmlund (1995), who use data from the Level of Living Survey (LNU), and the Household Market and Non-market Activities Survey (HUS)]. (vi) An equipment-to-structures ratio of 0.14 (Statistics Sweden). (vii) An average benefit replacement rate (computed as net-of-tax benefit entitlements as a percentage of net-of-tax earnings) of $84 \%$. (viii) A differential in the replacement rate across skills of ten percent points (Statistics Sweden). ( $i x$ ) Unemployment benefits outlays amount to $1 \%$ of GDP, as reported by the Swedish Unemployment Insurance Board (IAF). ( $x$ ) Welfare payments amount to about one fifth of total unemployment compensation (Labor Market Board, Insurance Unit).

Table 4 below presents our benchmark economy.

TABLE 4-PARAMETER VALUES

\begin{tabular}{|c|c|c|c|c|}
\hline Workers & Capitalists & Technology & Matching & Benefits \\
\hline$x_{s}=0.05$ & & $\sigma=-0.9$ & $\kappa=0.09$ & $\psi=0.2$ \\
\hline$x_{u}=0.95$ & $\beta=0.96$ & $\alpha=0.3$ & $a_{s}=3 \times 10^{-3}$ & $\varsigma=0.1$ \\
\hline$p=0.52$ & $\delta_{s t}=0.05$ & $\theta=0.36$ & $a_{u}=2 \times 10^{-4}$ & $B=0.28$ \\
\hline$N_{s}=22$ & $\delta_{e q}=0.125$ & $\lambda=0.48$ & $\rho=1.26$ & $d=0.1$ \\
\hline$N_{u}=19$ & & $\varphi=0.19$ & & $\gamma=-0.3$ \\
\hline
\end{tabular}

\section{The Rise of Centralization}

For these parameter values, a level of technology in the equipment sector equal to 0.8 , and a value of $\eta$ of 0.9 (i.e., the subjective probability on the bad equilibrium under decentralization), the centralized bargaining equilibrium of our model economy matches the observations for the 1970 Swedish economy listed above. To address the question of why unions opted for centralized bargaining in 1970, we present in Table 5 below unemployment rates and expected pre-matching workers' net incomes both under centralized and decentralized bargaining. Several comments on our results are in order. First, the two equilibria arising in the decentralized bargaining economy can be ranked in terms of pre- 
matching workers' net incomes: the equilibrium with low unemployment rates, DBE1, is associated with higher expected incomes. Second, the centralized bargaining equilibrium, CBE, yields lower unemployment rates than under decentralization. In terms of expected workers' income, centralized bargaining yields income levels below those in DBE1, but above income levels unions expect in DBE2. However, for the subjective probability on the occurrence of DBE2 in our calibrated economy, expected incomes in the centralized economy are higher than expected incomes under decentralization.

Therefore, centralized bargaining arises as the wage-setting arrangement in the 1970 economy. According to our theory labor unions for high-skilled workers embarked in centralized bargaining along with the low-skilled during the 50's, 60's and 70's because of the threat posed by the possibility of coordination failures under decentralization, which might otherwise have lessened workers income substantially.

TABLE 5-UNEMPLOYMENT RATES AND WORKERS EXPECTED INCOMES UNDER DECENTRALIZED AND CENTRALIZED BARGAINING

\begin{tabular}{|c|c|c|c|}
\hline & \multicolumn{2}{|c|}{ Decentralized Bargaining } & \multirow{2}{*}{$\begin{array}{c}\text { Centralized Bargaining } \\
\text { CBE }\end{array}$} \\
\hline & DBE1 & DBE2 & \\
\hline$u r_{s}$ & $0.74 \%$ & $1.1 \%$ & $0.6 \%$ \\
\hline$u r_{u}$ & $3.1 \%$ & $23.4 \%$ & $2.7 \%$ \\
\hline$u r_{\text {total }}$ & $3.0 \%$ & $22 \%$ & $2.6 \%$ \\
\hline$y_{s}$ & 0.7530 & 0.4689 & 0.5692 \\
\hline$y_{u}$ & 0.3004 & 0.2729 & 0.2869 \\
\hline
\end{tabular}

$\overline{\bar{N} \text { ote: } \text { Equilibrium values correspond to the economy with } q=0.8 \text { and the parameter values }}$ presented in Table 4 . Note that $y_{s}$ and $y_{u}$ denote expected pre-matching net incomes of highand low-skilled union workers, respectively.

The multiplicity of equilibria under decentralized bargaining results from the fiscal externalities created by the unemployment benefit program As mentioned above, this result hinges on the fact that a generous system of public insurance may be a cause macroeconomic instability and thus lead to the creation of new institutions - centralized wage bargaining - aimed at mitigating such instability. Complete unionization of the labor force implies that under centralization fiscal spillovers are fully internalized. The robustness of the multiplicity result with respect to the unemployment program's parameter values is 
explored below.

\section{The Fall of Centralization}

The hypothesis advanced in this paper regarding the collapse of centralized wage bargaining is the breakdown of the unions' alliance. That is, individual labor unions found that it was no longer in their interest to continue holding centralized wage negotiations. We show in this Section that the change in the wage-bargaining arrangement can be accounted for as the result of the two following trends observed in the Swedish economy between 1970 and 1990: 1) An increase in the level of technology in the equipment sector. According to estimates using relative prices of equipment, the average rate of equipmentspecific technological progress in the 1970-1990 period is around 3\%. This implies an increase in $q$ from 0.8 to 1.25 . 2) An increase in the relative supply of high-skilled labor. The proportion of the Swedish workforce with a university degree increased from $5 \%$ in 1970 to $15 \%$ in 1990 [see Edin and Holmlund (1995)].

Hence, we modify our benchmark economy to update $q$ and $x_{s}$ to their 1990 values, and show that our model accounts for the collapse of centralized wage negotiations. The results of this exercise are presented in Table 6 below. The decentralized equilibrium with high unemployment rates that was operating as a threat to decentralization in 1970 no longer exists in the 1990 economy. Equipment-specific technical progress renders equilibrium uniqueness under decentralized bargaining by increasing the productivity gap across workers. For given government aversion to inequality and given progressivity of benefits and taxes, the relative increase in the productivity of high-skilled labor leads to the violation of equilibrium conditions at the upper part of the Laffer curve. ${ }^{14}$ Therefore, workers' outside values to centralized bargaining are given by net incomes at the unique equilibrium that would emerge under decentralization. In other words, subjective probabilities on the outcome of holding decentralized negotiations are degenerate at equilibrium DBE1 in Table 6. For these outside values the bargaining set under centralization is empty. That is, there is no pair of equilibrium wage rates that can yield all coalitions of workers net incomes above their outside values. In short, according to our theory, equipmentspecific technological progress and the increase in the relative supply of high-skilled labor

\footnotetext{
${ }^{14}$ To gain further insight on how an increase in $q$ contributes to the removal of equilibrium multiplicity, we have prepared an on-line Appendix where we make a number of simplifying assumptions so that the equilibrium can be found by solving a system of two equations in two unknowns.
} 
caused the end of centralization via the removal of the threat of coordination failures in the decentralized economy.

TABLE 6-UNEMPLOYMENT RATES AND WORKERS EXPECTED INCOMES UNDER DECENTRALIZED AND

\begin{tabular}{lccc}
\multicolumn{4}{c}{ Centralized Bargaining } \\
\hline \hline & \multicolumn{2}{c}{ Decentralized Bargaining } & Centralized Bargaining \\
& DBE1 & DBE2 & CBE \\
\cline { 2 - 3 }$r_{s}$ & $2.5 \%$ & - & - \\
$u r_{u}$ & $2.0 \%$ & - & - \\
$u r_{\text {total }}$ & $2.0 \%$ & - & - \\
$y_{s}$ & 0.4273 & - & - \\
$y_{u}$ & 0.3275 & - & - \\
\hline \hline
\end{tabular}

$\overline{\overline{N o t e}: \text { Equilibrium values correspond to the economy with } q=1.25, x_{s}=0.15, x_{u}=0.85 \text { and }}$ parameter values presented in Table 4.

In addition to accounting for the collapse of centralization, our model's predictions are qualitatively in concordance with the patterns in unemployment and the skill premium observed in the Swedish economy between 1970 and the early 1990's. Regarding unemployment, the Swedish unemployment rate remained almost unchanged in the 80's, notwithstanding the sharp decline in centralization. The economy-wide unemployment rate in 1990 was $2 \%$, roughly the same rate as in $1970 .{ }^{15}$ Our model predicts the $2 \%$ unemployment rate in 1990, and hence that moving from full centralization to decentralization did not affect the unemployment rate in a significant manner. While our model overpredicts the unemployment rate among high-skilled workers, it does predict the drop in unemployment for low-skilled workers from $2.7 \%$ to about $2 \%$ in 1990.

Regarding the skill premium, the Swedish college-gymnasium wage differential declined during the 70's and the first half of the 80's, and then increased during the second half of the 80's and the 90's. ${ }^{16}$ By 1990 the Swedish skill premium was still more than $25 \%$ lower than in 1970. Our model yields a skill premium in 1990 that is less than half

\footnotetext{
${ }^{15}$ The Swedish unemployment rate experienced, however, an abrupt increase in the second half of the 90 's, to rates in the order of $8-9$ percent.

${ }^{16}$ This pattern is qualitatively similar to the one observed in the US economy, which constitutes the subject of study in KORV (2000). These authors explain the U-shaped time profile of the US skill premium as the net result of two opposite effects: a relative quantity effect, and a capital-skill complementarity
} 
the value matched in 1970. In our model, this decline is the net result of three effects: (i) the relative increase in high-skilled labor, a relative quantity effect; (ii) the relative increase in equipment capital, a capital-skill complementarity effect; and (iii) the decline in centralization, a wage-bargaining effect. The contribution of each of these effects to the skill premium is as follows. First, the increase in $q$ from 0.8 to 1.25 , holding the fraction of high-skilled workers fixed at $5 \%$, increases the skill premium from 0.6 to 0.95 . This is the capital-skill complementary effect. Next, the increase in $x_{s}$ from $5 \%$ to $15 \%$, holding the value of $q$ fixed at 0.8 , decreases the skill premium from 0.6 to 0.17 . This is the relative quantity effect. The last effect, the wage bargaining effect, cannot be quantified in the 1990 economy, since the bargaining set is empty under centralized negotiations. If we use, however, the centralized bargaining equilibrium and the "good" decentralized equilibrium (EQ1) of the 1970 economy to proxy this effect in the 1990 economy, we find that the bargaining effect amounts to an increase in the skill premium by $50 \%$, that is, going from centralization to decentralization, holding everything else constant, would increase the skill premium from 0.6 to 0.9 .

\subsection{Sensitivity Analysis}

In this section we conduct a sensitivity analysis with respect to selected parameters. We explore the effects of changes in the values of those parameters that play a prominent role either in shaping the fiscal externalities under decentralized wage bargaining —and thus in setting up the conditions for centralized bargaining - or in restoring equilibrium uniqueness after the increase in technology. We start out with our benchmark economy and then change the value of those key parameters. By so doing, we address two different but related questions. First, how robust are our results to changes in parameter values? Second, can we find patterns explaining the variation in the wage-setting arrangement across countries? The results from this exercise may be summarized as: (i) our results are fairly robust to parameter values; (ii) variation in parameter values that determine the generosity and progressivity of unemployment benefits, $\gamma, \psi$ and $\varsigma$, and the progressivity of taxation, $d$, have an unambiguous effect on multiplicity. The lower the generosity and effect. The first effect - the relative increase in the high-skilled labor input - contributes to reduce the skill premium. The second effect - the relative increase in capital equipment-contributes to increase the skill premium under equipment-skill complementarity. 
progressivity of benefits, and the progressivity of taxation, the less likely the possibility of multiple equilibria.

First we study the sensitivity of the multiplicity result with respect to parameters defining the social program: the government's attitude to inequality, $\gamma$; the eligibility to unemployment benefits, $\psi$; the progressivity of benefits, $\varsigma$; welfare payments $B$; and the progressivity of taxation, $d$. We set values for these parameters so that the externalities generated by the social program are just enough to yield multiple equilibria in the decentralized economy. That is, further changes in those parameters in the direction of weakening redistribution, progressivity and eligibility would result in a unique equilibrium under decentralization. These values are: $\gamma=0.15, \varsigma=0.06, B=0.19, d=0.04$ and $\psi=0.33$. These values define a program with progressivity in benefits less than three percent points, and an average eligibility of about two thirds of our benchmark economy. We have also explored how some of these parameters trade off in maintaining the multiplicity of equilibria. For instance, a decrease in the progressivity of benefits, $\varsigma$, from its benchmark value must be accompanied either by an increase in government's aversion for inequality (i.e., a decrease in $\gamma$ ) or by an increase in $B$ to restore equilibrium multiplicity. From this sensitivity exercise we conclude that the conditions for centralized wage bargaining are directly related to the generosity and progressivity of the social program. We use these results below to assess the cross-country differential in centralization scores.

The effects of changes in the production function's parameter values are as follows. The multiplicity of equilibria under decentralized bargaining is robust to changes in these parameter values. However, the extent to which equipment-specific technical change can restore equilibrium uniqueness - and thus cause the fall of centralization - depends on the differential in the elasticities of substitution between equipment and the two types of labor. That is, on the value of $\sigma$ relative to $\alpha$. Starting from our benchmark economy, we solve the model for higher values of $\sigma$ and find that for a value of this parameter as high as -0.1 equipment-specific technical progress would still have caused the collapse of centralization. Since Lindquist (2005) has shown that his estimate, $\sigma=-0.9$, is robust to different model specifications, a value of the order of -0.1 can be considered far beyond the range of estimated values for the Swedish economy.

Finally, one of the parameters we set using a priori information is the fraction of 
high-skilled workers in the labor force. Following related literature, we chose to define a high-skilled worker as a university graduate. Then - and to be consistent with this definition - we matched the skill premium using the university premium, and matched the unemployment rate of high-skilled workers as that among university graduates. This definition of high-skilled workers is not critical for our results. Our sensitivity analysis with respect to $x_{s}$ and the magnitude of its increase between 1970 and 1990 shows that our results are robust to the definition of high-skilled labor.

\subsection{Cross-Country Differentials in Centralization Scores}

In light of our model and the results above, we now turn our attention to wage bargaining in non-Scandinavian countries. Rather than aiming at a full accounting and explanation of bargaining institutions in those countries, we simply seek additional evidence supporting the mechanism for the rise and fall of centralization outlined in this paper. Thus, the type of question we address here is: can we, within the context of our model, provide some rationale for the low and medium levels of centralization in wage bargaining observed in non-Scandinavian economies?

According to Iversen's (1999) index, Italy had one of the most decentralized wagebargaining arrangements among Western European economies. For the period 1973-79, Iversen's index averaged 0.1978; for the period 1980-1986, it was 0.1410, and 0.1587 for the period 1987-1993. Italy's low centralization compares to that of the US, and is in sharp contrast to most of its neighboring countries, where centralization scores in the seventies were in the order of $0.3-0.35$. According to the theory developed in this paper, Italy's decentralization may be understood as a consequence of its lack of a proper program of unemployment benefits. ${ }^{17}$ Labor market policy in Italy has been stubbornly directed toward employment protection, leading to high firing restrictions and high severance payments.

\footnotetext{
${ }^{17}$ From the mid 40 's to the mid 80 's, unemployment benefits in Italy were essentially provided by the so-called cassa di integrazione. Benefits had a maximum duration of 13 weeks, and were non-universal, as they were granted only to workers employed in firms satisfying certain special conditions. The program was mainly designed to assist workers in firms engaged in the restructuring of their activities, or in firms affected by temporary productivity shocks non-attributable to the workers or the firms themselves. Workers receiving benefits were only temporarily fired, and remained on hold until the firm resumed activities.
} 
We argue that by turning away from a policy of unemployment benefits, Italy did not nurture the fiscal externalities that lie at the heart of centralized wage bargaining. A similar argument can be used to account for the highly decentralized wage-setting process in the US economy. With low benefit replacement rates, short benefit duration, and stringent eligibility conditions, the US unemployment benefit program seems to have fallen short of generating large enough externalities, which set the conditions for centralized bargaining.

In contrast to the Italian and US cases, we cannot resort to the absence of fiscal externalitites to rationalize the medium levels of centralization observed in many European countries in the early 1970's (e.g., Austria, Belgium, Germany, Netherlands and the UK). Although the generosity and progressivity of benefit programs in these countries did not reach the marks of the Swedish's, all these countries had fairly developed programs to assist the unemployed. Indeed, with the exception of the Netherlands where benefits were as generous as in Sweden, replacement rates in most of the other countries were only around 15 - 20 percent lower than in Scandinavian economies [see e.g., Martin (1996)]. Yet a more substantial difference between Scandinavian and non-Scandinavian benefit programs is the way they are handled. As we pointed out above, in non-Scandinavian countries benefit programs are compulsory, and do not call for worker affiliation with labor unions. Hence, unionization rates in these countries have remained in the range of $30 \%$ to $50 \%$. We argue that incomplete unionization may help explain why in these economies centralization did not attain Scandinavian standards. The implications of incomplete unionization for the extent of centralization in wage bargaining are the following. First, if non-unionized workers conduct their own wage negotiations, centralization scores are necessarily lower, even if unions choose to coordinate wage bargaining. Further, the union federation will be unable to fully internalize the fiscal externalities stemming from the wage-setting process. Second, in the case in which wages bargained by the union federation are extended to non-unionized workers, centralization will not reach maximum scores either. On the one hand, federation-bargained wages are less enforceable, as the federation in this case typically bargains a floor wage, and then allows full wage drift. On the other hand, union concentration is also significantly lower. Since Iversen's index includes measures of enforceability and union concentration, the medium levels of centralization in the above-mentioned countries may be explained by their relatively lower unionization rates. In sum, a generous and progressive program of unemployment benefits is a necessary, 
but not sufficient, condition for maximum centralization scores.

\section{Conclusions}

We have analyzed a model of wage bargaining that explains the evolution of the wagesetting process in Scandinavian economies. Our model is built upon the standard matching model, extended to include heterogeneity among workers, and both fiscal and technological links among these heterogeneous workers. Fiscal links in our model are created by a generous and progressive unemployment benefit program, which is funded by the government and administered directly by labor unions. Equipment-skill technical progress, along with equipment-skill complementarity, shape the evolution of the productivity gap across workers. Our analysis shows that when capital equipment is expensive and scarce, and, therefore, high- and low-skilled workers are relatively alike, the externalities stemming from the program of unemployment benefits can create coordination failures. Since coordination failures yield substantial losses in unions' income, centralized wage bargaining may arise as an equilibrium, thus explaining why Scandinavian countries held centralized wage negotiations until the early 80's. With the advent of technological progress, which increased the relative productivity of high-skilled workers, the possibility of coordination failures vanished. Thus, labor unions regained their role as individual wage negotiators. Our modeling of technological progress follows recent contributions, which have uncovered the nature of technological progress during the postwar period. A calibrated version of our model that takes into account the increase in technology successfully explains the rise and fall of centralization in wage bargaining.

Several important implications emerge from our results. A first implication relates to how the collapse of centralization should be assessed. Our theory shows that the collapse of centralization must be seen as the unions' response to technological progress, i.e., as a way of accommodating the bargaining arrangement to the new production technology. Accordingly, the fall of centralization might not be attributed to a shift in monetary policy or to a mismanagement of centralized bargaining agreements. This stands in sharp contrast to previous theories which place monetary policy at the center stage of the collapse of centralization and which seem to suggest a whole re-assessment of monetary policy in Europe. 
A second implication concerns the design of the unemployment benefit program, and its ability to bring into existence other labor market institutions. Highly generous and progressive benefit programs with government funding are bound to create fiscal externalities among labor unions. Under full unionization those externalities may end up triggering highly centralized wage-setting arrangements. This is an important consequence of the unemployment benefit program that has passed unnoticed in the literature. Our results thus introduce some new arguments which should not be dismissed in the debate on unemployment policy reform.

Our model can be extended along several directions. We have assumed that either all unions belong to the federation, or there is no federation, i.e., we have narrowed down the analysis to full centralization or full decentralization. It seems natural, however, to think of situations in which only a fraction of unions belong to the federation. Even though allowing for partial centralization will not change our conclusions, it will certainly give rise to new questions, and will shed further light on wage-bargaining institutions in non-Scandinavian economies. A second extension that can also open new avenues to the study of related problems is the consideration of inter-union solidarity arguments. As we pointed out above, our explanation for the rise and fall of centralization has intentionally abstracted from such issues. Our aim was to show that the extent of centralization in wage bargaining does not hinge on the extent of inter-union solidarity. Finally, our results suggest a number of testable propositions regarding wage-setting arrangements and social welfare programs. Empirical work along the lines set by our model will not only help confront our theory with the data, but will also bring new insights for future research. 


\section{References}

[1] Acemoglu, D., Aghion, P. and Violante. G.L. (2001). "Deunionization, Technical Change and Inequality," Carnegie-Rochester Conference Series on Public Policy, December, 55(1), pp. 229-264.

[2] Alesina, A. and Perotti, R. (1997). "The Welfare State and Competitiveness," American Economic Review, December, 87(5), pp. 921-939.

[3] Alexopoulos, M. and Cohen, J. (2003). "Centralized Wage Bargaining and Structural Change in Sweden," European Review of Economic History, 7, pp. 331-366.

[4] Blanchard, O. and Wolfers, J. (2000). "The Role of Shocks and Institutions in the Rise of European Unemployment: The Aggregate Evidence," Economic Journal, 110, pp. 1-33.

[5] Bleaney, M. (1996). "Central Bank Independence, Wage-Bargaining Structure, and Macroeconomic Performance in OECD Countries," Oxford Economic Papers, 48, pp. $20-38$.

[6] Cahuc, P. and Wasmer, E. (2001). "Does Intra-Firm Bargaining Matter in the Large Firm's Matching Model?," Macroeconomic Dynamics, 5, pp. 742-747.

[7] Cahuc, P., Marque, F. and Wasmer, E. (2008). "A Theory of Wages and Labor Demand with Intra-Firm Bargaining and Matching Frictions," International Economic Review, 49, pp. 943-972.

[8] Calmfors, L. and Driffill, J. (1988). "Bargaining Structure, Corporatism, and Macroeconomic Performance," Economic Policy, 6(April), pp. 14-61.

[9] Calmfors, L. (2001). "Wages and Wage-Bargaining Institutions in the EMU -A Survey of the Issues," Empirica, 28, pp. 325-351.

[10] Chae, S. and Heidhues, P. (2004). "Nash Bargaining Solution with Coalitions and the Joint Bargaining Paradox: A Group Bargaining Solution," Mathematical Social Sciences, 48, pp. 37-53. 
[11] Clasen, J. and Viebrock, E. (2008). "Voluntary Unemployment Insurance and Trade Union Membership: Investigating Connections in Denmark and Sweden," Journal of Social Policy, 37, pp. 433-452.

[12] Cukierman, A. and Lippi, F. (1999). "Central Bank Independence, Centralization of Wage Bargaining, Inflation and Unemployment: Theory and Some Evidence," European Economic Review, 43, pp. 1395-1434.

[13] Cukierman, A. and Lippi, F. (2001). "Labour Market and Monetary Union: A Strategic Analysis," The Economic Journal, 111(July), pp. 541-565.

[14] Daveri, F. and Tabellini, G. (2000). "Unemployment, Growth and Taxation in Industrial Countries," Economic Policy, 15, pp. 47-104.

[15] Davis, S. J. and Henrekson, M. (2005). "Wage-Setting Institutions as Industrial Policy," Labour Economics, 12, pp. 345-377.

[16] Delacroix, A. (2006). "A Multisectorial Matching Model of Unions," Journal of Monetary Economics, 53, pp. 573-596.

[17] Den Haan, W.J. (2007). "Shocks and the Unavoidable Road to Higher Taxes and Higher Unemployment," Review of Economic Dynamics, 10, pp. 348-366.

[18] Den Haan, W.J., Ramey, G. and Watson, J. (2000). "Job Destruction and Propagation of Shocks," American Economic Review, 90(3), 482-498.

[19] Edin, P.A. and Holmlund, B. (1995). "The Swedish Wage Structure: The Rise and Fall of Solidarity Wage Policy?" in Differences and Changes in Wage Structures," Freeman, R.B. and Katz, L., ed., The University of Chicago Press, Chicago and London.

[20] Freeman, R.B. and Gibbons, R.S. (1995). "Getting Together and Breaking Apart: The Decline of Centralized Collective Barganing," in Differences and Changes in Wage Structures, Freeman, R.B. and Katz, L., ed., The University of Chicago Press, Chicago and London. 
[21] Greenwood, J., Hercowitz, Z., and Krusell, P. (1997). "Long-Run Implications of Investment-Specific Technological Change," American Economic Review, 87(3), pp. 342-362.

[22] Heckman, J., Lochner, L. and Taber, C. (1998). "Explaining Rising Wage Inequality: Explorations with a Dynamic General Equilibrium Model of Labor Earnings with Heterogeneous Agents," Review of Economic Dynamics, 1(1), pp. 1-58.

[23] Holden, S, and Raaum, O. (1991). "Wage Moderation and Union Structure," Oxford Economic Papers, 43, pp. 409-423.

[24] Iversen, T. (1998). "Wage Bargaining, Central Bank Independence, and the Real Effects of Money," International Organization, 52(3), pp. 469-504.

[25] Iversen, T. (1999). "Contested Economic Institutions: The Politics of Macroeconomics and Wage Bargaining in Advanced Democracies," Cambridge: Cambridge University Press.

[26] Kalai, E. (1977). "Nonsymmetric Nash Solutions and Replications of 2-Person Bargaining," International Journal of Game Theory, 6, pp. 129-133.

[27] Kenworthy, L. (2001). "Wage Setting Coordination Scores," mimeo, Emory University.

[28] Krusell, P., Ohanian, L. E., Ríos-Rull, J. V. and Violante, G. L. (2000). "Capital-Skill Complementarity and Inequality: A Macroeconomic Analysis," Econometrica, 68(5), pp. 1029-1053.

[29] Lindquist, M. J. (2005). "Capital-Skill Complementarity and Inequality in Sweden," Scandinavian Journal of Economics, 107, pp. 711-735.

[30] Lundberg, E. (1985). "The Rise and Fall of the Swedish Model," Journal of Economic Literature, 23(1), pp. 1-36.

[31] Martin, J. P. (1996). "Measures of Replacement Rates for the Purpose of International Comparisons: A Note," OECD Economic Studies, 26, pp. 99-116. 
[32] Morris, S. and Shin, H.S. (2003). "Heterogeneity and Uniqueness in Interaction Games," Cowles Foundation Discussion Paper No. 1402, Yale University.

[33] Rocheteau, G. (1999). "Balanced-budget Rules and Indeterminacy of the Equilibrium Unemployment Rate," Oxford Economic Papers, 51, pp. 399-409.

[34] Rotemberg, J. J. (2006). "Cyclical Wages in a Search-and-Bargaining Model with Large Firms," NBER Working Paper Series No. 12415.

[35] Soskice, D. and Iversen, T. (1998). "Multiple Wage-Bargaining Systems in the Single European Currency Area," Oxford Review of Economic Policy, 14(3), pp. 110-124.

[36] Stole, L.A. and Zwiebel, J. (1996). "Intrafirm Bargaining under Non-Binding Contracts," Review of Economic Studies, 63, pp. 375-410.

[37] Summers, L., Gruber, J. and Vergara, R. (1993). "Taxation and the Structure of Labor Markets: The Case of Corporatism," Quarterly Journal of Economics, 108(2), pp. $385-411$.

[38] Velasco, A., and Guzzo, V. (1999). "The Case for a Populist Central Banker," European Economic Review, 43(7), pp. 1317-1344.

[39] Visser, J. (2000). "A Combined Indicator of Union Centralization and Coordination," Working Paper No. 00/3, Amsterdam Institute for Advanced Labour Studies. 